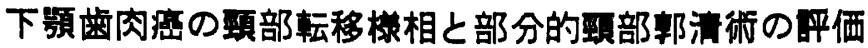

\author{
岡本学・大関 悟・平河孝慧・原厷子 \\ 田代英焳
}

\section{Evaluation of partial neck dissection based on the mode of cervical lymph node metastasis in lower gum cancer}

\author{
Manabu Okamoto - Satoru Ozeki - Takanori Hirakawa \\ Hiroko Hara - Hideo TASHIRo
}

\begin{abstract}
Among 41 primary patients with squamous cell carcinoma of the lower gum treated at our Department of Oral Surgery between 1961 and 1980, 21 patients received neck dissection because of possible cervical lymph node metastasis. In these patients, mode of the cervical lymph node metastasis was examined and the application of partial neck dissection was evaluated.

Metastasis to the lymph nodes had histological confirmation in 11 patients. However the metastasis were all confined to the upper neck region (submental, submandibular and superior internal jugular nodes) but the contralateral submandibular lymph nodes were also involved in 3 cases. Primary lesions of these 3 cases were located in the anterior part of the lower gum.

Partial neck dissection was performed on 12 patients and 6 had histologically positive lymph nodes. Two of them had recurrence in superior internal jugular region, although the primary lesions were under control. In these cases there were many large metastatic lymph nodes that firmly adhered to the surrounding tissuese. Subsequent secondary radical neck dissection was difficult.

It was concluded from these findings that the radical neck dissection is be indicated for lower gum cancer when clinical signs of neck metastasis are noticed. When partial neck dissection is indicated for unavoidable reasons, it is necessary to thoroughly dissect the supraomohyoid region.
\end{abstract}

Key words: lower gum cancer, cervical lymph node metastasis, neck dissection

緒 言

当科に㧍ける口腔癌の治療は，一般に䫟部リンパ節転 䔟のない症例では原発巣のみの切除, あるいは組織内照 射を主に行い, 頸部リンバ節転移の疑われる症例では頸 部郭清術を併せて, 可能であれば en bloc の切除を行

九州大学歯学部第 1 口腔外科学教室

（主任：田代英雄教授）

First Department of Oral Surgery, Faculty of Dentistry, Kyushu University (Chief: Prof. Hideo Tashiro)

受付日：昭和 60 年 5 月 2 日
5.しかし下頞齿肉癌では頸部転移の疑いがない症例で も下顎骨切除に際して㖽下部が術野に含まれるので, 㴿 下部を中心にした部分的頸部郭清術を施行した症例が多

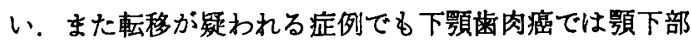
のリンパ節に転移が疑われることが多いことから，全身 疾患の合併や高龄のために全頸部郭清術が行之ない場合 には，顎下部およびオトガイ下部の郭清のみにとどめる ことも多く, 他部位に比較して部分的頸部郭清術を行う 症例が多い，舌癌における部分的頸部郭清術はその頸部 リンバ節転移様相や治療成績の検討より，意義は少ない といわれている ${ }^{123)}$. 今回著者らは下䫛雨肉癌症例の頸 部リンパ節転移の様相ならびに部分的頸部郭清術施行例 の治療経過上り，下額歯肉癌における部分的頸部郭清術 
衰 1 全顼部部消街迹行症例の TNM 分数

\begin{tabular}{c|cccc}
\hline & T 1 & T 2 & T 3 & T 4 \\
\hline$N_{0}$ & 1 & & 1 & \\
$N_{1}$ & & 1 & 1 & 2 \\
$N_{3}$ & & 1 & 1 & 1 \\
\hline
\end{tabular}

全例: $\mathbf{M}_{0}$

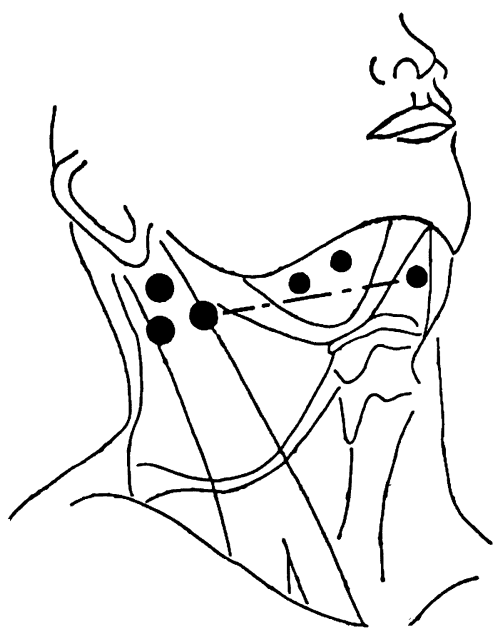

图 1 全到部郭消㧓施行症例飞おける 転移部位（5 例）

の意義について検討を加えたので報告する。

\section{対 象 症 例}

対象とした症例は，1961年 1 月より1980年12月までの 20年間に九州大学附属病院口腔外科で治療を行った下顎 齿肉扁平上皮癌新鮮症例41例中, 頸部郭清術を施行した 21例である，21例の内訳は，初回郭清時に全頸部郭清術 を施行した 9 例と, 部分的顒部郭清術を施行した12例で ある.

TNM 分類は1978年 UICC 分類 ${ }^{4)}$ に従い, 頸部リン パ節の分類は日本頭頸部連湟学会による頭頸部癌取扱い 規約 ${ }^{5)}$ に従い行った。

なお行われた部分的欧部郭清術式は, 顎下部とオトガ イ下部の一塊とした郭清が主体で, 郭清時に上内深頸部 に腫大したリンパ節を触知する場合は同領域のリンパ組 織の郭清が行われた。

結果

1. 下預崡肉密における頸部リンパ節転移の持相 全頸部郭清術を施行した 9 例の TNM 分類は表 1 の

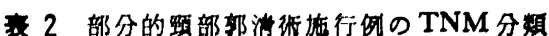

\begin{tabular}{|c|c|c|c|c|c|}
\hline & $\mathrm{T} 1$ & T 2 & T 3 & T 4 & 部分的䢀消御を㴧択した理由 \\
\hline $\mathbf{N}_{0}$ & 1 & 3 & 2 & & 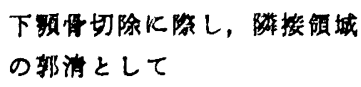 \\
\hline $\begin{array}{l}N_{1} \\
N_{3}\end{array}$ & 1 & 4 & & 1 & 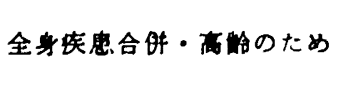 \\
\hline
\end{tabular}

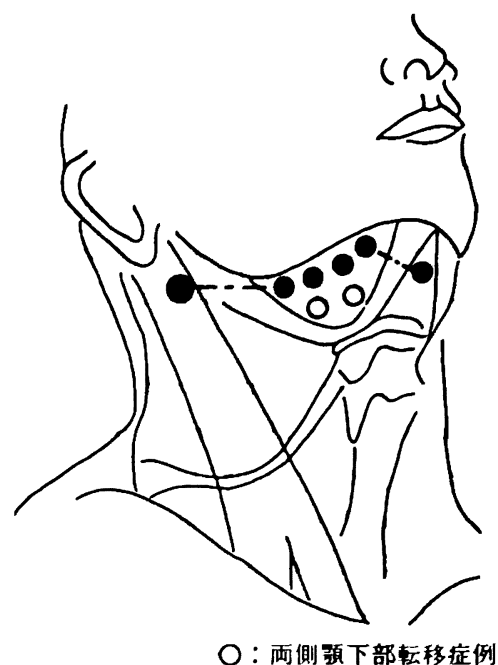

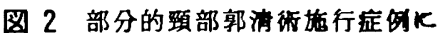
扣ける枟移部位（6 例）

ごとくであった.このらち5例に組織学的にリンバ節転 移を認めた。 5 例の郭清術施行時期は， 3 例は原発巣治 療と同時, 1 例は初診時 $\mathrm{N}_{0}$ で原発策治療後約 1 年目に 後発転移を認め郭清術を施行し，1 例は原発巣治㞠後約 4 年 8 か月目に原発巣の再発と同時に転移をきたし施行 した． 5 例の転移部位は，図1のごとく額下部のみ 2 例, 上内深頙部のみ 2 例, オトガイ下部之上内深頚部に 認められたもの1例であった。

次に部分的頸部郭清術を施行した 12 例の TNM 分類 は表 2 のごとくであった. $\mathbf{N}_{0}$ の 6 例はいずれも下䝷骨 切除に際して，䫓下部が術野に含まれるため顥下部を中 心とした予防的な部分的䫫部郭清㭪を施行し, $\mathrm{N}_{1 \sim 3}$ の症 例は, 5 例は全身疾患合併の理由で， 1 例は高龄の理由 で全頸部郭清術が適応でないと判断し，部分的頸部郭清 術を選択した. 12例の5ち 6 例 $\left(\mathrm{N}_{0} 2\right.$ 例, $\mathrm{N}_{1} 3$ 例, $\mathrm{N}_{3}$ 1 例）に組織学的転移を認めた。その転移部位は図 2 の

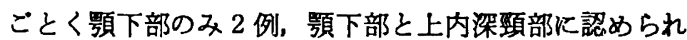
たもの 1 例, オトガイ下部と顥下部に認められたもの 1 例であり，残り 2 例は反対側の䅡下部にもリンパ節腫大 を認め，そのリンバ節摘出を行い，組樴学的転移を認 


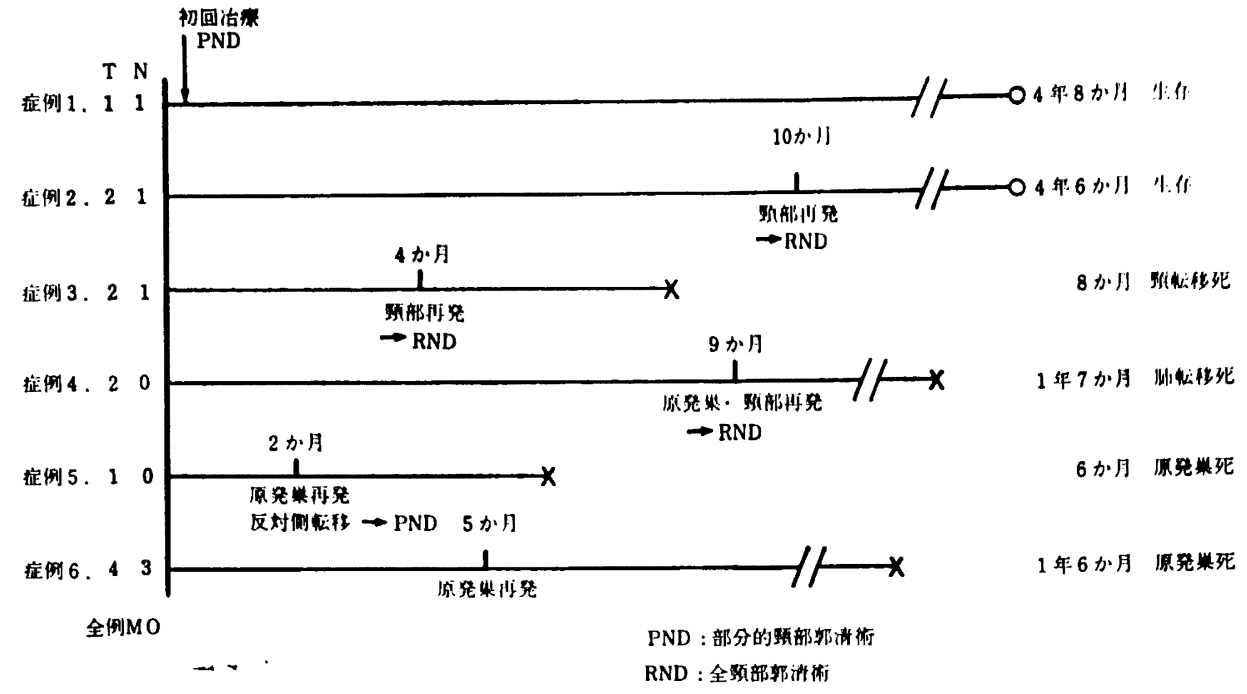

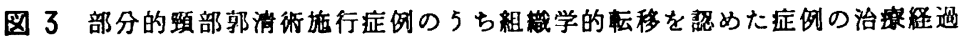

应田 2

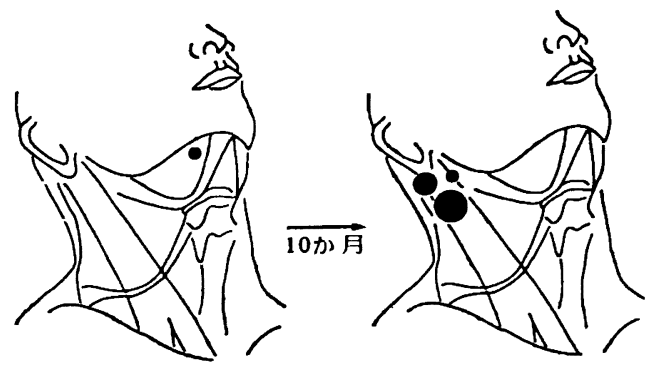

应洌 3

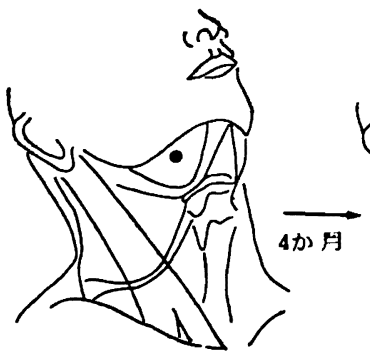

部分的頊部新清時

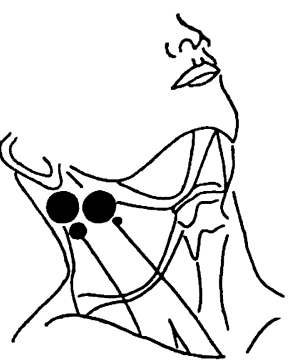

頝部再発時
图 4 㲁部再発症例の再発様相

め, 両側䫇下部の転移症例であった.

\section{2. 部分的頸部部清街施行症例の治療释過}

組織学的転移を認めた 6 例は図 3 のごとく，症例 1 は 原発巣, 䫜部とすに再発なく生存し, 症例 2,3 源発
巣の再発はなく, 初回治療より10か月目と4 か月目に頸 部再発をきたした．その時点で全顕部郭清術を施行し， その転移様相は图 4 に示すように，いずれる上内深頸部 に 4 個と 3 個の転移リンパ節を認め, 最大リンパ節長径 は $38 \mathrm{~mm}, 35 \mathrm{~mm}$ で, 周囲組織との瘾着が強度であっ

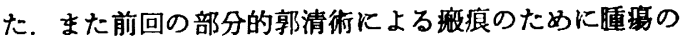
境界がはっきりせず，尰埸の上端が頭蓋底へ近接し，内 頸静脈の切離が困難であったりして手術が困難で, 術中 尰瘍への切り込みをおこした。症例 2 は全頸部郭清後 4 年 6 か月再発なく生存し, 経過良好であった. 症例 3 は 全頸部郭清後, ${ }^{60} \mathrm{Co} 4400 \mathrm{rad}$ の術後照射を行ったが, 約 1 か月後にオトガイ下部，前頸部に再発をきたし，制 御不可能で初回治療開始より8 か月目に死亡した.

症例 4, 5 は初回治療後, 原発巣再発之同時に頚部再 発を認めた，症例 4 は原発巣の 2 次治療と全頊部郭清術 を施行した。 この症例では部分的領部郭清を上内深頸部 まで行っていたので，再発はオトガイ下部，中内深頸部 に認めた。頸部再発の制御はなされたものの肺転移をき たし，初回治療開始より約 1 年 7 か月目に死亡した. 症 例 5 は前崡部症例で原発策再発と同時に反対側顎下部に 転移を認め，反対側の部分的頸部郭清術を施行したが， さらにオトガイ下部への再発を羿め, 制御しえず死亡し た.

症例 6 は頙部再発は認めなかったが, 原発巣の再発を きたし，初回治療より1年 6 か月後に原発巣死した（図 3 ).

部分的頸部郭清術を施行し, 組織学的転移を認めなか った 6 例はいずれる経過中に頙部リンパ節への転移は認 めず, 3 例は 5 年以上生存, 1 例は 4 年11か月生存中, 
1 例は 1 年 2 か月目に原発然死，残り 1 例は 2 年目以阵 追跡不能であった。

\section{考察}

\section{1. 下頻迷肉密の頸部リンパ節枟移の㴍相について}

一般に口腔癌の頸部リンパ節枟移はその解剖学的リン バ流の走行と一致して起こり，㭧側の顥下リンハ節，上 内深项リンバ節に多く想められ，これらの領城は口胫痁 の一次リンパ節と考えられている0,7，著者らが先飞蛝 告8)した結果では，舌癌を主体とした口胫满における頸 部リンバ節転移はその約 $68 \%$ が上内深頸リンパ節であ ク，ついで䫑下リンパ節（約 $49 \%$ ）に多く認められた。

下䪽歯肉部のリンパ流は，前歯部ては影下リン八節か オトガイ下リンパ節へ流れ，煩側歯部では顥下リンハ 節へ，舌側白歯部では䫑舌骨筋を穿通し，顆下リンパ 節へ流れ，時に後走して直接上内深頸リンバ節へ流れ $3^{0,10)}$

今回, 自験例では下頻歯肉癌の転移部位はオトガイ下 リンパ節，䫑下リンハ節，上内深頸リンハ節のいわゆる Level I・II の領域に限局して認められた. 戸塚ら ${ }^{11)}$, Byers $5^{12)}$ 同様に Level I ・ II の領域に転移が限局 していたことを報告している。これに対して宮川ら ${ }^{13)} は$ Level I・II K多かったすのの, Level IV への転移症 例を報告している。，一方，舌癌，口底癌における転移部 位をみると，当科における検索臬では，Level I ・II に 多いか， Level III・IV の領域への転移症例（舌癌 $25 \%$, 口底癌50\%) る認めた。特に舌癌に関しては，Donegan 5), Droulias 5 ${ }^{14)}$ は上位のリンパ流を経由せずに下方 の領域へ流れるリンバ流の存在について述へ，頸部のい ずれの部位にも転移を起こすこと，転移は Level I・II

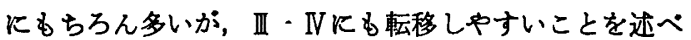
ており，同様の報告は多い(15 17) 自駼例飞おいても，中 内深頸リンパ節，下内深頸リンパ節に単一の転移を認め た症例があった ${ }^{8}$. 宮川 $5^{13)}$ む舌癌では Level I〜III わたる広範用の転移を強調している，以上のことより， 下影歯肉癌の転移様相は舌癌，口底癌とは若干異なるよ らに思われる。 その理由として部位によるリンバ流の違 いとともに, 非可動粘膜部と可動粘膜部といら違いが考 えられたが，転移部位に影響するかは明らかでない， た著者ら ${ }^{8)}$ は，転移リンパ節の個数が増加するに従い, 複数の領域へ転移する傾向があり，その結果として Level III・IV への転移が多くなることを報告したか， 下顠歯肉癌では転移リンパ節が 3 個および 5 個の症例で む Level I・II に限局していた.

前崡部症例では，その転移時期が左右で異なるもの の，3例とも両側の顎下リンパ節に転移を認めたこと は, 前齿部症例においては反対側への転移の可能性を十 分に考虑して処置方針を決定することが必要であると思
われた，今後さらに症例数を追加し模封を加えていきた い.

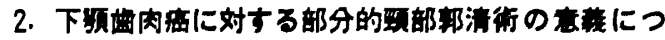
いて

まず部分的到部部消術の術式飞ついて みると，松浦

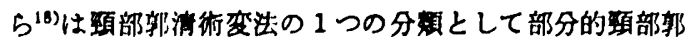

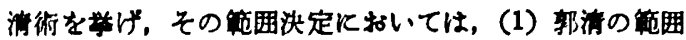
が解剖学的に明確な境界で囲まれた覑城であること， （2）原発栄切除偠する手術野に含まれること，(3) リ

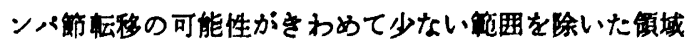
であること，としており，原発柴の部位応して德々の

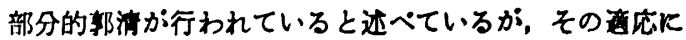
ついては明確にしていない. Brown ら

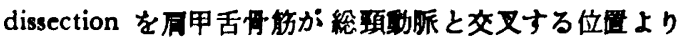
上方の領域で，耳下腺下部1/3を含んた部消としており， その際胸鎖釈突筋は保存している。 また suprahyoid neck dissectionは影下三角部に限った郭清として，口 腔癌の 郭清䉇用としては不十分であると迢ぺている。 Winston $5^{20}$ は suprahyoid neck dissection を穎下りン

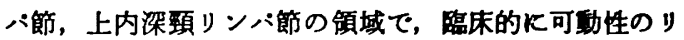
ンパ節を蚛知する場合に行っている．当科における術式 では，影下部郭清を主体として，症例により上内深影り ンバ節のリンパ組織郭清を行ってきたが，この方法では 上内深頸リン八節の郭清が不十分になるよらである.

したがって部分的顓部郭清術の郭清籁囲としては，局 甲舌骨筋のレベルまで術野を抬大し，いわゆる supraomohyoid neck dissection 飞より，胸鎖乳突筋を後方へ 十分に茟引できるようにする必要があると思われた。

部分的頸部部清訹の意義については，舌癌，口底癌で は否定的な見解が多い上らである. Donegan ら”は，舌 飞関してそのリンバ流より影部のいずれの領城へる枟移 する可能性があることから，部分的郭清術の道応はこくく

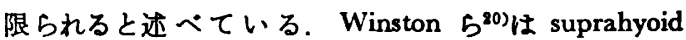
neck dissection を行った症例と全頸部郭清症例との比艾 検討にて, 組織学的枟移があった症例では再発率に有意 差がないが、転移のなかった症例では suprahyoid neck dissection の方が再発率が有意倞かったこと，再発例 では病巣の範囲が広く，再手術が困奞であったと述へて いる．小野 $5^{2)}$ は舌癌で病巣が小さく，触知リンバ節が オトガイ下部、䫑下部に限局した症例に partial neck dissection を行い，原発巣の再発なく顠部再発した症例 が50\%で，全渞部郭清症例のそれが26\%であったことに 比へ高率であったこと，また予後に約 $30 \%$ の差がみられ たこと， partial neck dissection 施行後の再転移に対す る郭清症例は予後不良であったこと，などより，よほど の理由がなければ全頸部郭清術をすべきであると結論し ている. 作田 ${ }^{3)}$ は歯肉癌, 口底癌に多く施行した上玨部 郭清症例の项部再発が約 $43 \%$ ，全顠部郭清症例のそれ が0\%であるのに比へ高率であったと述べている. 今回 
著者らは，下顥丵肉癌をとりあげて部分的郭清症例の治

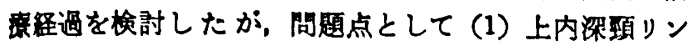
八節に頸部再発が多かった，(2）再発のリンハ笛はその 長径が大きく，周囲組樴との瘾着が強度で再手術に困難 をきたした，（3） $\mathrm{N}_{0}$ 症例で部分的郭消をした 6 例中 2 例飞組樴学的枟移を垫めたことが举げられる。

まず上内深頚リンパ節へ頱部再発が多かったことに成 しては，下頻幽肉では上位の領域に限局した転移であ ったが，䫑下リンパ節のみに転移した症例は6/11例 (55 \%)であり，上内深頊りンパ節に転移を認めた症例は4/ 11例 (36\%) でこの領城への転移す比校的多い，従来の 当科の術式では胸鎖乳突筋下居の郭清が十分でなく，と くに同筋肉の乳栚突起付着部に近い此校的高位に頭部再 発が多いことはそのことを示している．著者ら"11は頸部 郭清後の頭部再発の原因の 1 つとして内项㬹眽の保存に よる上内深顓りンハ節の郭清が不十分であった可能性を 述べた．さらに下方の領城への転移が完全には否定でき ないことや，初回手術による疫痕等による follow up の 困奞さ，手術操作を困奞とする再発転移の様相から下額 歯肉癌の場合においてもやはり全頸部郭清術が第一選択 であるべき考える。

一方, Byers $5^{\text {12) }}$ は下影齿肉密では supraomohyoid

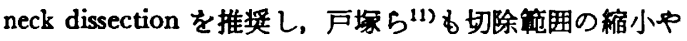
手術時間の短樎による形態, 機能の保存や手術の安全性 から下影齿肉癌に対しては, supraomohyoid neck dissectionを検討すべきことであるとの見解を述へている. 今回の自馀例の中には部分的顡部郭清術のみで頸部転移 を制御できた症例や顠部再発後に全頚部郭清術を行い, 顓部転移を制御できた症例もあり，全身的な要因などで やむをえない症例では部分的賈部郭清術も意義があると 思われる。.また術野飞含まれる理由で予防的郭清術を施 行した 6 例の $\mathrm{N}_{0}$ 症例のらち 2 例に組織学的転移を認 め, このことからる郭清の意義はあるものと思われ，こ れらの場合の郭清範囲としては額下部のみならず, 上内 深顠リンバ節を十分に郭清すべきであり，そのためには omohyoid muscle まで拡大した郭清が必要であると思わ れる.

\section{結論}

20年間に当科で治療した下顎幽肉扁平上皮癌新鲜症例 のうち，頚部郭清術を施行した21例について，その顕部 リンパ節転移様相および部分的䫫部郭清術施行例の治療 経過を検討して，以下の結論を得た。

1. 下頡歯肉癌では，その頸部リンパ節転移はオトガ

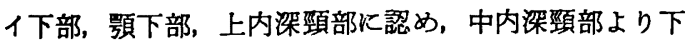
方の領域への転移はなかった。

2. 額下部のみの転移は $6 / 11$ 例 (55\%) で, 上内深頙 部の転移は4/11例 (36\%) 飞認めた。
3. 前梅部症例 3 例はナべて反対侧龭下部にも枟移を 蹋め，雨側転移症例であった，

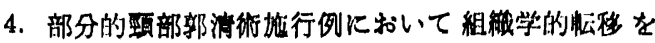

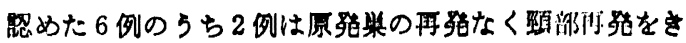
たした，再発はいずれも上内深影りンバ笛で，枟移りン

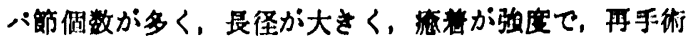
は困難であった。

5. 部分的頸部新淜術施行例のらち2 例はそれだけで 頸部転移を制御できた。

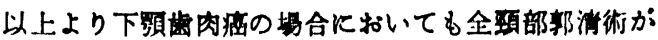
第 1 選択であるべきと考えるが，全身的な要因などでや むをえない症例では部分的影部部消術です意䋐があると 思われた，その際の郭消笻明としては supraomohyoid neck dissection が必要である.

本論文の要旨は，第29回日本口腔外科学会総会（札璂 市，1984年）に括いて報告した。

\section{引用 文 献}

1) Donegan, J.O., Gluckman, J.L., et al: The role of suprahyoid neck dissection in the management of cancer of the tongue and floor of the mouth. Head \& Neck Surg 4: 2092121982.

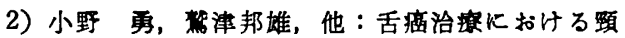
部郭消行の評洒。癌の臨床 26: 123-130 1980.

3）作田正義：癌細胞の転移形成に関寸万研究。口 科誌 28: 525-539 1979.

4) Harmer, M.H.: TNM Classification of Malignant Tumors. 3rd Ed, UICC, Geneva, 1978, p 23-26.

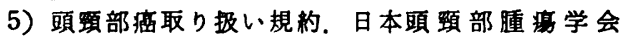
篇， 肘，金原出版，東京，1982，2-4頁.

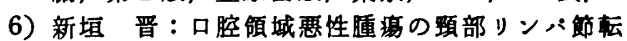
移に関する臨床病理学的研究. 日外誌 25: 784-797 1979.

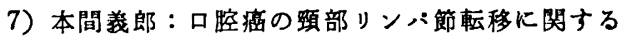
研究. 日外誌 28: 1667-1684 1982.

8）岡本学, 大関语, 他：口腔癌に打ける影部 郭清循施行例の检討。颙部 ンンハ・節転移様相と 予後。日口外誌 31：95-103 1985.

9）上條雍彦：口腔解剖学 3 脈管学. 第 9 版, フナ 卜一么社, 東京, 1976, 付21-22頁.

10) Ackerman, L.V. and Regato, J.A.: Cancer. 3rd Ed, Mosby, Saint Louis, 1962, p 320-322.

11）戸塚靖則，水越孝典，他：下影药肉扁平上皮瘦 の臨床的研究. 日外誌 31: 36-51 1985.

12) Byers, R.M., Newman, R., et al: Results of treatment for squamous carcinoma of the lower gum. Cancer 47: 2236-2238 1981.

13）宮川明, 小浜源郁, 他：口腔瘦の頚部りンパ 節転移に関する躘床病理学的检討。日口外誌 
29: 1555-1561 1983.

14) Droulias, C. and Whitehurst, J.O.: The lymphatics of the tongue in relation to cancer. Am Surg 42: 670-674 1976.

15）典田稔，吉井功，他：舌㾞の枟移につい $\tau$. 耳喉 36: 907-913 1964.

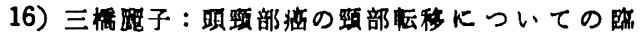

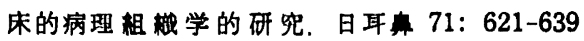
1968.

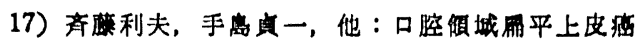

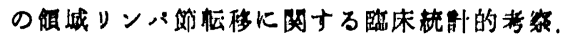
日口外部 25: 778-78.3 1979.

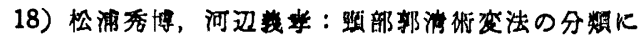

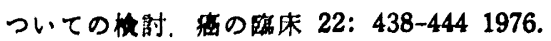

19) Brown, J.B. and McDowell, F.: Neck Dissection. 1st Ed, Charles C. Thomas Pub, Springfield, 1954, p 74-80.

20) Winston, C. and Strawitz, J.G.: Results in suprahyoid modified radical, and standard radical neck dissections for metastatic squamous cell carcinoma. recurrence and survival. Am J Surg 136: 512-515 1978.

21) Ozeki, S., Okamoto, M., et al: Cervical recurrence following radical neck dissection for carcinoma of the oral cavity. Fukuoka Acta med. 76: 37-43 1985. 